\title{
COMPARATIVE VALUE OF MICROSCOPY, SEROLOGY AND REAL TIME PCR IN THE DIAGNOSIS OF ASYMPTOMATIC CANINE LEISHMANIA INFANTUM INFECTION
}

Diagnostic validity of microscopy in asymptomatic canine Leishmaniosis

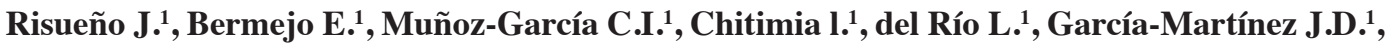
Goyena E. ${ }^{1}$, Fisa R. ${ }^{2}$, Riera C. ${ }^{2}$, Jiménez-Montalbán P. ${ }^{3}$, Martínez-Ramírez A. ${ }^{3}$, MeseguerMeseguer J.M. ${ }^{3}$, Murcia L. ${ }^{4}$, Segovia M. ${ }^{4}$, Berriatua E. ${ }^{*}$

${ }^{1}$ Facultad de Veterinaria, Universidad de Murcia, España. ${ }^{2}$ Facultad de Farmacia, Universidad de Barcelona, España. ${ }^{3}$ Centro Municipal de Zoonosis, Ayuntamiento de Murcia, Murcia, España. ${ }^{4}$ Facultad de Medicina, Universidad de Murcia, España.

* Corresponding author: Eduardo Berriatua. Facultad de Veterinaria, Universidad de Murcia, España. Tel.: 0034868883997. Fax: 00348684147 E-mail address: berriatu@um.es

Historial del artículo:

Recibido: 27 mayo 2012

Aceptado: 3 septiembre 2012

\begin{abstract}
The sensitivity (SE) of cytological examination of spleen and lymphnode smears by optical microscopy (OM), antibody-ELISA (enzyme-linked immunosorbent assays) and real-time (rt) PCR (polymerase chain reaction), for diagnosing asymptomatic canine Leishmania infantum infection was investigated in 110 apparently healthy dogs from southeast Spain. The percentage of OM, ELISA and rtPCR positive dogs were $2 \%(2 / 110), 27 \%$ (26/97) y 67\% (39/58), respectively, although the percentage of rtPCR-positive dogs were $35-41 \%$ in individual tissues and $9 \%$ in blood. The estimated SE (95\% confidence interval) of OM relative to the rtPCR and ELISA tests was 5\% (0-12) and 8\% (0-18), respectively. Results confirm that most apparently healthy dogs from L. infantum endemic areas are infected, that approximately only one third of these infected dogs develop antibodies and that very few have parasite loads that are high enough to allow detection by OM. As a result, the degree of agreement between rtPCR, ELISA and OM for L. infantum diagnosis in subclinnically infected dogs is low.
\end{abstract}

Key words: cytology, ELISA, Leishmania infantum, optical microscopy, PCR. 


\section{RESUMEN}

Se investigó la sensibilidad (SE) del examen citológico mediante microscopia óptica (MO) de improntas de bazo y linfonodo, de la prueba de anticuerpos ELISA (inmuno-ensayo ligado a enzima) y de la PCR (reacción en cadena de la polimerasa) a tiempo real (tr), para diagnosticar la infección asintomática por Leishmania infantum en 110 perros aparentemente sanos, del sureste de España. El porcentaje de perros positivos a MO, ELISA y PCRtr fue $2 \%$ (2/110), 27\% (26/97) y 67\% (39/58), respectivamente, aunque el porcentaje de PCRpositivos osciló entre 35-41\% para cada tejido individualmente y $9 \%$ en sangre. La SE estimada (intervalos de confianza del 95\%) de la MO en relación a la PCRtr y al ELISA fue 5\% (0-12) y 8\% (0-18), respectivamente. Estos resultados confirman que la mayoría de perros aparentemente sanos de una población endémica de $L$. infantum están infectados, que aproximadamente solo la tercera parte de éstos desarrolla anticuerpos frente al parásito y solo unos pocos tienen suficiente carga parasitaria en tejido linfoide como para ser detectada mediante MO. Consecuentemente, el grado de concordancia de la PCRtr, el ELISA y la MO en el diagnóstico de leishmaniosis canina asintomática es escaso.

Palabras clave: citología, ELISA, Leishmania infantum, microscopía óptica, PCR.

\section{INTRODUCTION}

Leishmania infantum and its American counterpart, L. chagasi (syn. L. infantum) are zoonotic protozoan parasites transmitted by phlebotomine sandflies, which cause Canine Visceral Leishmaniosis (CVL). They target the monocyte-macrophage cell lineage and there is now evidence that infection in endemic areas is widespread with $40-80 \%$ of dogs being positive to highly sensitive polymerase chain reaction (PCR) tests (Solano-Gallego et al., 2009). Most PCR-positive animals are latently infected and asymptomatic, and the many do not have circulating antibodies detectable by epidemiologically useful indirect immunofluorescence (IFI) and enzyme-linked imunosorbent assays (ELISA). Seropositive dogs however, have a greater risk of developing clinical Leishmaniosis compared to infected seronegative expressing protective cellmediated immunity (Baneth et al., 2008; Miró et al., 2008; Gomes et al., 2008; Solano-Gallego et al., 2009).

Diagnosis based on cytological examination by optical microscopy (OM) of stained lymphoid tissue and bone marrow smears remains a reference technique because it allows direct detection of the parasite and it is routinely used in clinical practice to confirm infection in dogs with clinical signs (Gomes et al., 2008; Maia and Campino, 2008). Under a trained eye, OM specificity (SP) may be close to absolute instead, sensitivity (SE) can be greatly variable depending on the presence or absence of clinical signs and other factors such as the quality and number of samples and OM fields examined (Saridomichelakis et al., 2005). Reported se of $\mathrm{OM}$ in lymphoid tissue and bone marrow smears relative to the PCR, ranged from $30 \%$ to $95 \%$ in dogs with CVL symptoms and was $8 \%$ to $39 \%$ in asymptomatically infected dogs (Ikonomopoulus et al., 2003; Saridomichelakis et al., 2005; Moreira et al., 2007). Moreover, OM se in blood smears is significantly lower compared to tissue and a recent report detected amastigotes in $0.28 \%$ of blood smears from L. infantum-infected and mostly symptomatic dogs (Giudice and Passantino 2011).

Subclinically infected dogs are important control wise as they may transmit infection to sandflies (Molina et al., 1994). Among them OM-positive dogs are likely to have a greater parasite load, be more efficient transmitters and possibly have a greater risk of developing disease, although this has not been investigated. 
A further problem is that clinical signs of CVL can be highly variable leading to uncertainty when classifying dogs as symptomatic or asymptomatic (de Ybañez et al., 2009). In this scenario is important to have more information on the value of cytological examination in infected yet healthy-looking dogs. The present study addresses this issue as part of a wider investigation of CVL in southeast Spain.

\section{MATERIALS AND METHODS}

\section{Study population and sampling}

The study included 110 Leishmania asymptomatic, $\geq 1$ year-old pet dogs from Murcia in southeast Spain where CVL is endemic (Chitimia et al., 2011). Animals collected by the local authority from owners not willing to keep them, were clinically examined to identify symptoms of CVL (Solano-Gallego et al., 2009, de Ybañez et al., 2009), prior to euthanasia by intraperitoneal sodium pentobarbital infection. Immediately after EDTA-blood, popliteal lymphnode, spleen and nasal skin samples were taken and transported in ice to the laboratory. Within two hours of taking the samples, spleen and lymphnode smears were prepared on 76x26 $\mathrm{mm}^{2}$ glass slides, dried in air and fixed in methyl alcohol ready for staining, blood tubes were centrifuged to separate plasma for ELISAantibody analysis and it was stored frozen like remaining blood and tissue and later used for DNA extraction and PCR testing.

\section{L. infantum laboratory diagnosis}

Tissue smears were stained using the rapid panoptic method following manufactures instructions and preparations, sealed with a $24 \times 50 \mathrm{~mm}^{2}$ coverglass, were examined by two members of the research team unaware of the dog's PCR and ELISA status, at x1000 magnification to identify amastigotes appearing as round to oval $2-5 \mu \mathrm{m}$ in diameter basophilic bodies with internal organelles including the nucleus and kinetoplast (Ash and Orihel, 2007).

Two commercial ELISA kits namely, Ingezim $^{\circledR}$ (Ingenasa, Spain) and Civtest ${ }^{\circledR}$ (Laboratorios Hipra, Spain) were used to detect anti-leishmania antibodies and antibody optical densities were used to classify samples as negative, positive or inconclusive, in undiluted plasma samples, as instructed by manufacturers. The SE and SP of Ingezim has not been reported in contrast, Civtest SE and SP in relation to the IFI test, is claimed by manufactures to be $98 \%$ y $96 \%$, respectively.

DNA from tissue and blood samples was extracted using a robot (Maxwell ${ }^{\circledR} 16$, Promega). A specific and highly sensitive TaqMan probe real time PCR was used to detect $L$. infantum kinetoplast DNA sequences, using 300ng of template DNA and 40 cycle sets, as described by Mary et al., (2004) with modifications by Martín-Ezquerra et al., (2009). Test were carried out in duplicate and a threshold amplification cycle $\left(\mathrm{C}_{\mathrm{T}}\right)$ was estimated for each sample as a semiquantitative measure of parasite DNA load (Gomes et al., 2008). Samples with $\mathrm{C}_{\mathrm{T}}$ values ranging 1-35 and 36-40 were considered clear and weakly positive, respectively.

\section{Statistical analysis}

EpiInfo 6 (CDC Atlanta, USA) was used to assess differences in the proportion of positivetest results according to dog explanatory variables including sex, age and breed using Yate's corrected chi-squared test, to compare $\mathrm{C}_{\mathrm{T}}$ means using non-parametric analysis of variance and to calculate percentage agreement and kappa coefficients (k) for diagnostic test comparisons. $\mathrm{K}$ ranges from 0.00 (agreement as expected by chance) to 1.00 (complete agreement) and values $>0.81,0.61-0.80,0.41$ $0.60,0.21-0.40$ and $>0.00-0.20$ indicate almost perfect, substantial, moderate, fair and slight agreement, respectively (Thrusfield, 1998). 


\section{RESULTS}

\section{Frequency of OM, ELISA and PCR positive dogs}

Amastigotes were observed in macrophages in three samples from two dogs including two lymphnode and one spleen smears hence, the percentage of OM Leishmania-positive asymptomatic dogs was $2 \%(2 / 110)$, with a $95 \%$ confidence interval ranging $0-4 \%$. Both dogs were 2 year-old males and included a purebred Mastín and a crossbred (Table 1).

The percentage of dogs testing PCR-positive in at least one tissue or blood sample was $67 \%$ (39/58), and was $41 \%(22 / 54)$ in spleen, $42 \%$ (22/52) en lymphnode, 35\% (15/43) in skin and 9\% (7/79) in blood (Table 1). Although the percentage of PCR-positives did not differ statistically according to sex, age or breed, it was numerically greater in 1 and 2 year-olds compared to older dogs, males than females and crossbreds compared to purebreds $(\mathrm{p}>0.05)$ (Table 1). The mean $\mathrm{C}_{\mathrm{T}}$ for PCR-positive samples did not vary significantly according to the sample type and the overall mean, minimum and maximum $\mathrm{C}_{\mathrm{T}}$ for positive samples were 31 , 12 and 40 , respectively, and $89 \%(59 / 66)$ and $21 \%(14 / 66)$ of samples had $\mathrm{C}_{\mathrm{T}} \geq 22$ and $\mathrm{C}_{\mathrm{T}}>35$, respectively.

As shown in table 1, the percentage of antibody-positive dogs to any of the two ELISA tests was $27 \%(26 / 97)$ and was $22 \%$ (20/92) to Ingezim and 25\% (24/96) to Civtest ( $>0.05)$. Seroprevalence was greater for males than females according to Ingezim and no other significant differences in seroprevalence were observed according to other explanatory variables examined $(\mathrm{p}>0.05)$ however, seroprevalence increased numerically with age, and was greater in males than females and in pure compared to crossbred dogs (Table 1).

\section{Relationship between OM, ELISA and PCR results and estimated OM sensitivity}

OM-positive dogs were seropositive according to both ELISA tests and the only one of these two dogs tested by PCR was positive in spleen and lymphnode tissue, with $\mathrm{C}_{\mathrm{T}}$ values of 17 and 12, respectively. Moreover, all ELISApositive dogs tested by PCR were PCR-positive. Assuming that both OM positive dogs were PCR-positive, the ratio of OM-positive to PCRpositive would be $2 / 40$, so OMs SE and $95 \%$ confidence interval (CI) would be $5(0-12) \%$. Similarly, OM-positive to ELISA-positive ratio would be $2 / 26$ and OM SE (95\% CI) relative to ELISA would be $8(0-18) \%$.

Overall, 92\% (84/91) of dogs had identical Ingezim and Civtest ELISA results, 5 dogs were Civtest positive and Ingezim negative and the opposite was the case for $2 \operatorname{dogs}$ and $\mathrm{k}=$ 0.79 indicating substantial agreement between ELISA tests (Table 2).

Agreement between PCR results according to sample type was lower and the percentage of identical results ranged from $70 \%$ for spleen and lymphnode and $63 \%$ for lymphnode and blood (table 2); k (s.e.) ranged from $0.11(0.06)$ for lymphnode or spleen and blood and 0.53 (0.14) for spleen and lymphnode, indicating slight and fair agreement, respectively (Table 2).

Comparisons between ELISA, PCR and OM indicated extensive variation in the $\%$ and degree of agreement and the later was either slight or fair in all cases (Table 2); the \% of agreement was highest for ELISA-Ingezim and blood PCR (83\%) and the degree of agreement was highest for ELISA-Civtest and tissue PCR (0.37) and lowest for OM and tissue PCR (0.02) (Table 2). 


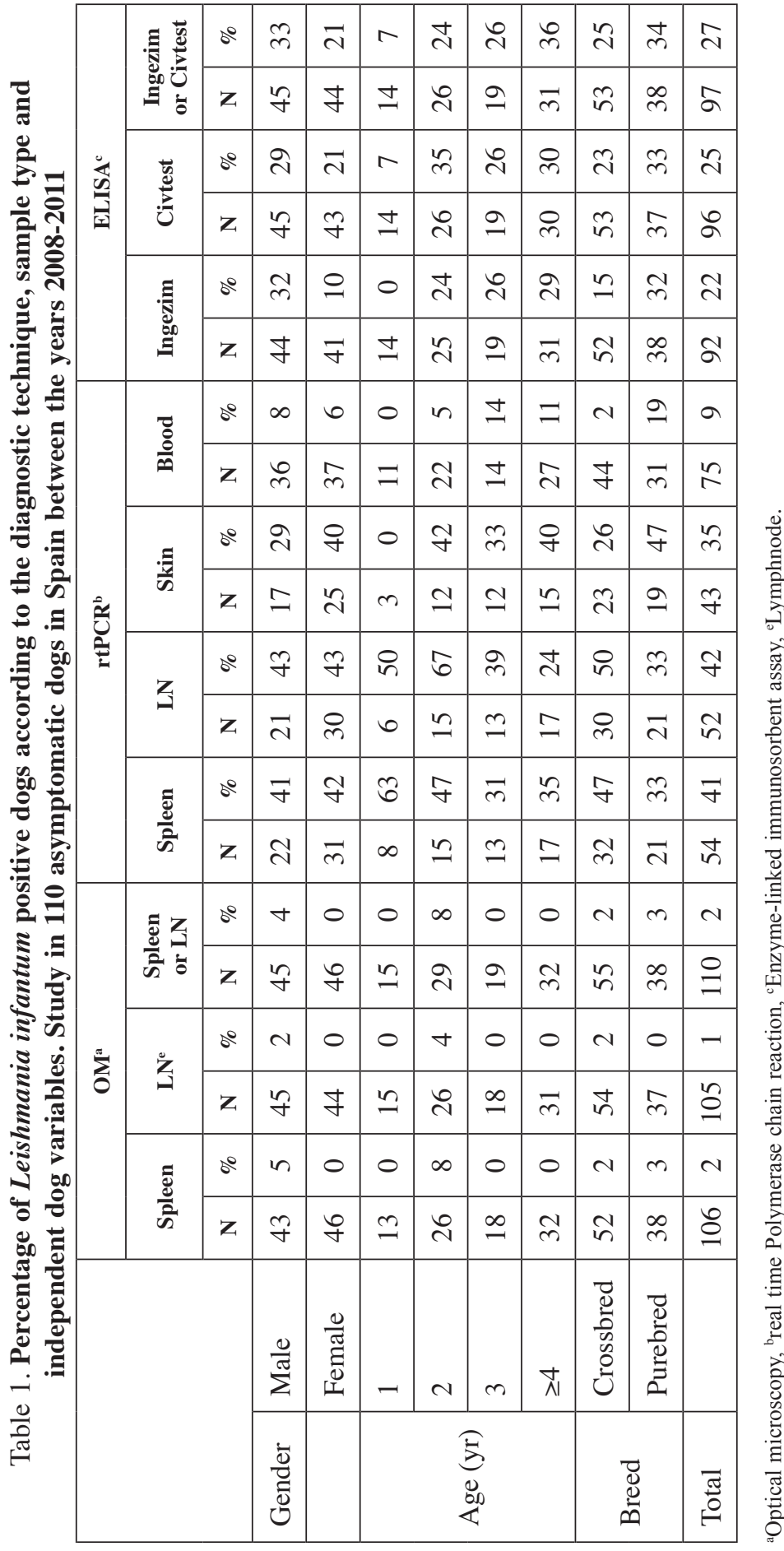


Table 2. Percentage agreement and kappa results for $\mathbf{E L I S A}^{\mathrm{b}}, \mathbf{r t P C R}^{\mathrm{c}}$ and $\mathbf{O M}^{\mathrm{d}}$ tests for diagnosing Leishmania infantum infection in dogs. Study in 110 asymptomatic dogs in Spain between the years 2008-2011

\begin{tabular}{|c|c|c|c|c|}
\hline \multirow[b]{2}{*}{ Test and sample } & \multirow{2}{*}{$\begin{array}{c}\% \\
\text { agreement }\end{array}$} & \multicolumn{3}{|c|}{ kарpa } \\
\hline & & $\mathbf{k}$ & s.e. ${ }^{a}$ & $\begin{array}{c}\text { degree of } \\
\text { agreement }\end{array}$ \\
\hline \multicolumn{5}{|l|}{ ELISA $^{\mathrm{b}}$} \\
\hline Ingezim; Civtest & 92 & 0.79 & 0.10 & Substantial \\
\hline \multicolumn{5}{|l|}{$\mathrm{rtPCR}^{\mathrm{c}}$} \\
\hline Spleen; lymphnode & 77 & 0.53 & 0.14 & Moderate \\
\hline Spleen; skin & 67 & 0.28 & 0.15 & Fair \\
\hline Spleen; blood & 64 & 0.11 & 0.06 & Slight \\
\hline Lymphnode; skin & 64 & 0.28 & 0.15 & Fair \\
\hline Lymphnode; blood & 63 & 0.11 & 0.06 & Slight \\
\hline Skin; blood & 70 & 0.17 & 0.08 & Slight \\
\hline ELISA Ingezim; tissue ${ }^{\mathrm{d}}$ rtPCR & 57 & 0.24 & 0.10 & Fair \\
\hline ELISA Ingezim; blood rtPCR & 83 & 0.35 & 0.10 & Fair \\
\hline ELISA Civtest; tissue $^{\mathrm{d}}$ rtPCR & 65 & 0.37 & 0.12 & Fair \\
\hline ELISA Civtest; blood rtPCR & 78 & 0.28 & 0.09 & Fair \\
\hline OM; Ingezim & 80 & 0.15 & 0.05 & Slight \\
\hline OM; Civtest & 77 & 0.12 & 0.04 & Slight \\
\hline OM; tissue ${ }^{d}$ rtPCR & 34 & 0.02 & 0.02 & Slight \\
\hline OM; blood rtPCR & $\mathrm{NA}^{\mathrm{e}}$ & NA & NA & NA \\
\hline
\end{tabular}

${ }^{\mathrm{a}}$ Standard error, ${ }^{\mathrm{b}}$ Enzyme-linked immunosorbent assay, ${ }^{\mathrm{c}}$ real time Polymerase chain reaction, ${ }^{\mathrm{c}}$ Optical microscopy, ${ }^{\mathrm{d}}$ positive in spleen, lymphnode or skin, ${ }^{\mathrm{d} N o t}$ applicable since OM positives were not PCR tested in blood

\section{DISCUSSION}

The present study provides a quantitative estimation of the percentage of L. infantuminfected asymptomatic dogs testing positive to cytological examination by $\mathrm{OM}$ of lymphoid tissue smears, rtPCR test and antibody-ELISA. The percentage of OM positive dogs was $2 \%$ in contrast, $67 \%$ were rtPCR-positive and $27 \%$ were ELISA positive. The estimated se $(95 \% \mathrm{CI})$ of OM was $5(0-12) \%$ and $8(0-$ $18) \%$ relative to the PCR and the ELISA test, respectively. A similarly low se was reported by Saridomichelakis et al (2005) in a group of 52 L. infantum PCR-positive asymptomatic dogs infection and contrast with those in a study in Brazil reporting L. chagasi-positive lymphnode smears in $39 \%$ of 23 asymptomatic dogs examined (Moreira et al., 2007). Study discrepancies could be related to differences in the incidence of infection between study areas and in the stage of infection of the animals examined: Possibly, the dogs in Murcia had lower exposure and parasite load, and/or were in an earlier phase of infection compared to those in the Brazilian study. Host-parasite differences between $L$. chagasi and L. infantum influencing diagnostic sensitivity have not been described and they are considered the same species with the former originating from L. infantum carried over by European dogs. Some variability between studies could also be related to the 
number of dogs examined which was greatest in the present study, to differences in sample preparation: good aspirates can be difficult to obtain in dogs with small lymphnodes, and to the researcher's skill to recognize CVL clinical signs in infected dogs and amastigotes in sample preparations (Saridomichelakis et al., 2005; de Ybañez et al., 2009). Some of these problems can also be extended to diseased dogs leading to similarly large variability in OM se estimates (Ikonomopoulus et al., 2003; Saridomichelakis et al., 2005; Moreira et al., 2007) and to some experts considering OM observation of lymphoid tissue smears as a generally unreliable technique to diagnose CVL (Baneth and Aroch, 2008).

The large proportion of rtPCR-positive and to a lesser extent of ELISA-positive dogs is common in CVL endemic areas including Spain where conditions favor extensive transmission (Solano-Gallego et al., 2001; Baneth et al., 2009). Seroprevalence is typically lower than PCR-prevalence because many infected dogs do not develop antibodies, which are considered ineffective in controlling the parasite (Baneth etal., 2008). rtPCR prevalence however, depended on the sample type, it was lowest in blood samples and it was considerably increased by analyzing several tissues per animal. These results indicate that asymptomatic animals have low parasite loads and that parasitemia is comparatively rare in asymptomatically infected dogs; it would be useful from a clinical and control point of view to assess the transmission efficiency of these dogs according to their rtPCR status. ELISA-1 seroprevalence was greater for males than females; several studies have reported greater prevalence among large males, arguing that they are commonly used as guard dogs and kept outside the house, permanently exposed to phlebotomine bites (Fisa et al., 1999; Alonso et al., 2010) or as a result of increased mortality among infected females during pregnancy, delivery and nursing (Fisa et al., 1999).
To conclude, the study provides evidence that parasitological diagnosis by microscopical observation of lymphoid tissue smears may lack sensitivity to diagnose infection in clinically healthy $L$. infantum infected dogs and that the rtPCR test is the preferred method because it detects infected dogs that typically have or do not have an antibody-mediated immune response. Whilst OM has little epidemiological value in terms of estimating infection prevalence it could be useful in combination with other techniques, to improve our understanding of parasite transmission and possibly, to identify dogs requiring close monitoring and other with untypical CVL clinical signs in need of treatment, particularly where other more sophisticated diagnostic tests cannot be performed.

\section{ACKNOWLEDGEMENTS}

The research in this article was funded by "Fundación Séneca" of the Región de Murcia" (Pr.Ref:08714/PI/08), the "Ministerio de Ciencia e Innovación" and the "Red de investigación de enfermedades tropicales del Instituto de Salud Carlos III (RICET RD06/0021/1007)" and the "Excelentísimo Ayuntamiento de Murcia".

\section{REFERENCES}

ALONSO F, GIMÉNEZ FONT P, MANCHÓN M, RUIZ DE YBÁÑEZ R, SEGOVIA M, BERRIATUA E. 2010. Geographical variation and factors associated to seroprevalence of canine leishmaniosis in an endemic Mediterranean area. Zoonoses Public Health 57(5):318-28.

ASH LR, ORIHEL TC. 2007. Atlas of human Parasitology. $5^{\text {th }}$ edition. American Society for Clinical Pathology Press.

BANETH G, AROCH I, 2008. Canine leishmaniasis: a diagnostic and clinical challenge. Veterinary Journal 175(1):14-5.

BANETH G, KOUTINAS AF, SOLANOGALLEGO L, BOURDEAU P, FERRER, L. 
2008. Canine leishmaniosis - new concepts and insights on an expanding zoonosis: part one. Trends in Parasitology 24(7):324-30.

CHITIMIA L, MUÑOZ-GARCÍA CI, SÁNCHEZ-VELASCO D, LIZANA V, DEL RÍO L, MURCIA L, FISA R, RIERA C, GIMÉNEZ-FONT P, JIMÉNEZ-MONTALBÁN P, MARTÍNEZRAMÍREZ A, MESEGUER-MESEGUER JM, GARCÍA-BACETE I, SÁNCHEZISARRIA MA, SANCHIS-MONSONÍS G, GARCÍA-MARTÍNEZ JD, VICENTE V, SEGOVIA M, BERRIATUA E. 2011. Cryptic Leishmaniosis by Leishmania infantum, a feature of canines only? A study of natural infection in wild rabbits, humans and dogs in southeastern Spain. Veterinary Parasitology 181(1):12-6.

DE YBÁÑEZ RR, DEL RÍO L, MARTÍNEZCARRASCO C, SEGOVIA M, COX J, DAVIES C, BERRIATUA E, 2009. Questionnaire survey on Canine Leishmaniosis in southeastern Spain. Veterinary Parasitology 164(2-4):124-33

FISA R, GÁLLEGO M, CASTILLEJO S, AISA MJ, SERRA T, RIERA C, CARRIÓ J, GÁlleGO J, PORTÚS M. 1999. Epidemiology of canine leishmaniosis in Catalonia (Spain): The example of the Priorat focus. Veterinary Parasitology 83(2):87-97.

GOMES YM, PAIVA CAVALCANTI $M$, LIRA RA, ABATH FG, ALVES LC. 2008. Diagnosis of canine visceral leishmaniasis: biotechnological advances. Veterinary Journal 175(1):45-52.

GUIUDICE E, PASSANTINO A. 2011. Detection of Leishmania amastigotes in peripheral blood from four dogs. Acta Veterinaria Hungarica 59(2): 205-213.

IKONOMOPOULOS J, KOKOTAS S, GAZOULI M, ZAVRAS A, STOITSIOU M, GORGOULIS VG. 2003. Molecular diagnosis of leishmaniosis in dogs. Comparative application of traditional diagnostic methods and the proposed assay on clinical samples. Veterinary Parasitology 113(2):99-113.

MAIA C, CAMPINO L 2008. Methods for diagnosis of canine leishmaniasis and immune response to infection. Veterinary Parasitology 158(4):274-87.

MARY C, FARAUT F, LASCOMBE L, DUMON H, 2004. Quantification of Leishmania infantum DNA by a real-time PCR assay with high sensitivity. Journal of Clinical Microbiology 42,5249-5255.

MARTÍN-EZQUERRA G, FISA R, RIERA C, ROCAMORA V, FERNÁNDEZ-CASADO A, BARRANCO C, SERRA T, BARÓ T, PUJOL RM. 2009. Role of Leishmania spp. infestation in nondiagnostic cutaneous granulomatous lesions: report of a series of patients from a Western Mediterranean area. British Journal of Dermatology 161(2):3205.

MIRÓ G, CARDOSO L, PENNISI MG, OLIVA G, BANETH G. 2008. Canine leishmaniosis--new concepts and insights on an expanding zoonosis: part two. Trends in Parasitology 24:371-7.

MOLINA R, AMELA C, NIETO J, SANANDRES M, GONZALEZ F, CASTILLO JA, LUCIENTES J, ALVAR J, 1994. Infectivity of dogs naturally infected with Leishmania infantum to colonized Phlebotomus perniciosus. Transactions of the Royal Society of Tropical Medicine and Hygiene 88(4):491-3.

MOREIRA MA, LUVIZOTTO MC, GARCIA JF, CORBETT CE, LAURENTI MD, 2007. Comparison of parasitological, immunological and molecular methods for the diagnosis of leishmaniasis in dogs with different clinical signs. Veterinary Parasitology 145(3-4):245-52.

SARIDOMICHELAKIS MN, MYLONAKIS ME, LEONTIDES LS, KOUTINAS AF, BILLINIS C, KONTOS VI, 2005. Evaluation of lymph node and bone marrow cytology 
in the diagnosis of canine leishmaniasis (Leishmania infantum) in symptomatic and asymptomatic dogs. American Journal of Tropical Medicine and Hygiene 73:82-6.

SOLANO-GALLEGO L, MORELL P, ARBOIX M, ALBEROILA J, FERRER L, 2001. Prevalence of Leishmania infantum in dogs living in an area of canine leishmaniasis endemicity using PCR on several tissues and serology. Journal of Clinical Microbiology 39, 560-63.
SOLANO-GALLEGOL, KOUTINAS A, MIRÓ G, CARDOSO L, PENNISI MG, FERRER L, BOURDEAU P, OLIVA G, BANETH G. 2009. Directions for the diagnosis, clinical staging, treatment and prevention of canine leishmaniosis. Veterinary Parasitology 165, 1-18.

THRUSFIELD M. 1995. Veterinary Epidemiology, $2^{\text {nd }}$ edition. Blackwell Sciences, Oxford, United Kingdom. Chapter 13, 178198. 